\title{
NMR Spectroscopy for Protein Higher Order Structure Similarity Assessment in Formulated Drug Products
}

\author{
Deyun Wang ${ }^{1}$, You Zhuo ${ }^{2}$, Mike Karfunkle ${ }^{3}$, Sharadrao M. Patil ${ }^{2}$, Cameron J. Smith ${ }^{4}$, David A. Keire ${ }^{5}$ and \\ Kang Chen $2, *$ (D)
}

1 Northeast Medical Products Laboratory, Office of Regulatory Science, Office of Regulatory Affairs, U.S. Food and Drug Administration, Jamaica, NY 11433, USA; deyun.wang@fda.hhs.gov

2 Division of Complex Drug Analysis, Office of Testing and Research, Office of Pharmaceutical Quality, Center for Drug Evaluation and Research, U.S. Food and Drug Administration, Silver Spring, MD 20993, USA; you.zhuo@fda.hhs.gov (Y.Z.); sharadmpatil@gmail.com (S.M.P.)

3 Division of Pharmaceutical Analysis, Office of Testing and Research, Office of Pharmaceutical Quality, Center for Drug Evaluation and Research, U.S. Food and Drug Administration, St. Louis, MO 63110, USA; mike.karfunkle@fda.hhs.gov

4 Division of Liquid Based Products I, Office of Lifecycle Drug Products, Office of Pharmaceutical Quality, Center for Drug Evaluation and Research, U.S. Food and Drug Administration,

Silver Spring, MD 20993, USA; cameron.smith@fda.hhs.gov

5 Office of Testing and Research, Office of Pharmaceutical Quality, Center for Drug Evaluation and Research, U.S. Food and Drug Administration, St. Louis, MO 63110, USA; david.keire@fda.hhs.gov

* Correspondence: kang.chen@fda.hhs.gov; Tel.: +1-240-402-5550

check for updates

Citation: Wang, D.; Zhuo, Y.; Karfunkle, M.; Patil, S.M.; Smith, C.J.; Keire, D.A.; Chen, K. NMR Spectroscopy for Protein Higher Order Structure Similarity Assessment in Formulated Drug Products. Molecules 2021, 26, 4251. https: / / doi.org/10.3390/ molecules26144251

Academic Editor: Robert Brinson

Received: 21 May 2021

Accepted: 8 July 2021

Published: 13 July 2021

Publisher's Note: MDPI stays neutral with regard to jurisdictional claims in published maps and institutional affiliations.

Copyright: (C) 2021 by the authors Licensee MDPI, Basel, Switzerland. This article is an open access article distributed under the terms and conditions of the Creative Commons Attribution (CC BY) license (https:/ / creativecommons.org/licenses/by/ $4.0 /)$.

\begin{abstract}
Peptide and protein drug molecules fold into higher order structures (HOS) in formulation and these folded structures are often critical for drug efficacy and safety. Generic or biosimilar drug products (DPs) need to show similar HOS to the reference product. The solution NMR spectroscopy is a non-invasive, chemically and structurally specific analytical method that is ideal for characterizing protein therapeutics in formulation. However, only limited NMR studies have been performed directly on marketed DPs and questions remain on how to quantitively define similarity. Here, NMR spectra were collected on marketed peptide and protein DPs, including calcitonin-salmon, liraglutide, teriparatide, exenatide, insulin glargine and rituximab. The $1 \mathrm{D}^{1} \mathrm{H}$ spectral pattern readily revealed protein HOS heterogeneity, exchange and oligomerization in the different formulations. Principal component analysis (PCA) applied to two rituximab DPs showed consistent results with the previously demonstrated similarity metrics of Mahalanobis distance $\left(\mathrm{D}_{\mathrm{M}}\right)$ of 3.3 . The $2 \mathrm{D}^{1} \mathrm{H}_{-}{ }^{13} \mathrm{C}$ HSQC spectral comparison of insulin glargine DPs provided similarity metrics for chemical shift difference $(\Delta \delta)$ and methyl peak profile, i.e., $4 \mathrm{ppb}$ for ${ }^{1} \mathrm{H}, 15 \mathrm{ppb}$ for ${ }^{13} \mathrm{C}$ and $98 \%$ peaks with equivalent peak height. Finally, $2 \mathrm{D}^{1} \mathrm{H}_{-}{ }^{15} \mathrm{~N}$ sofast $\mathrm{HMQC}$ was demonstrated as a sensitive method for comparison of small protein HOS. The application of NMR procedures and chemometric analysis on therapeutic proteins offer quantitative similarity assessments of DPs with practically achievable similarity metrics.
\end{abstract}

Keywords: similarity metrics; Mahalanobis distance; chemical shift difference; peak profile; relative peak height

\section{Introduction}

Complex generic and biosimilar drug products (DPs) are increasingly developed and comprehensive analysis of these DPs is the foundation for their regulatory approval [1-4]. The active pharmaceutical ingredient (API) or drug substance (DS) in protein DPs ranges in size from short peptides to large monoclonal antibodies (mAbs). The native folding of proteins, heterogeneity, dynamic exchange between conformations, oligomerization and aggregation profile in a formulation are collectively called the higher order structure (HOS) properties of protein therapeutics and are typically critical for efficacy and safety [5]. 
Protein HOS is stabilized by weak hydrogen bonding, electrostatic and hydrophobic forces, which are solvent dependent, and, consequently, formulation differences affect HOS [6-9]. In addition, proteins can be chemically modified either purposely, e.g., pegylation, or unintentionally, e.g., oxidation, which could introduce variability to protein HOS [10-12]. All these factors and the accompanying sensitivity to solution conditions necessitate characterizing the protein chemistry and HOS with minimal perturbation to the formulation by ideally using DPs [13]. In addition, the analytical means to assess protein HOS in a formulation are desired for generic and biosimilar drug developers that mostly only have access to the marketed originator DPs that are usually deemed as the reference DPs.

With the development of higher field strength magnets and cryogenic probes, modern high-resolution NMR spectroscopy is a non-invasive and sensitive method for protein molecular structure characterization [14-18]. However, several assumptions among stakeholders have limited the application of NMR on formulated DPs. The first is that strong excipient signals in a DP would interfere with weak DS signals such that NMR spectra would be dominated by the peaks of the excipients and would not be useful for protein HOS assessment. Indeed, NMR for protein HOS characterizations [19] has been applied on proteins extracted from DP [20-22], proprietary DS or non-marketed DP [23-25], which aimed to demonstrate the applicability of modern heteronuclear NMR to characterize proteins with ${ }^{15} \mathrm{~N}$ and ${ }^{13} \mathrm{C}$ nuclei at natural abundances.

Second, the lack of acceptable metrics for similarity assessment means that most comparisons have been made at a visual level. The question of the level of similarity that is practically measurable remains to be answered quantitively. Previous attempts were made to collect NMR spectra on a DS enriched formulation of filgrastim [26] and DP formulations of insulin [27]. A combined chemical shift difference of $8 \mathrm{ppb}$ or less was proposed as the threshold for experimental precision in 2D-NMR comparisons of biosimilars using data between the US and Indian marketed filgrastim DPs [26]. The principal component analysis (PCA) of the insulin DP NMR spectra revealed the practically achievable similarity threshold expressed in Mahalanobis distance $\left(D_{M}\right)$ to be 3.3 or less [27]. These values were achieved when $600 \mathrm{MHz}$ spectrometer with room temperature probe was used, therefore, the derived metrics were practical (in terms of the availability of instruments) and could be useful in establishing the acceptance criteria for a certain DP before and after a manufacturing change and for the comparison between a generic or biosimilar protein and the reference DP. However, their validity has not been further tested.

Third, the type of HOS properties reliably measured from DPs using modern NMR is not entirely clear. Herein, $1 \mathrm{D}^{1} \mathrm{H}$ NMR spectra were acquired on a range of marketed DPs with protein molecular weights ranging from $3 \mathrm{kDa}$ to $145 \mathrm{kDa}$ and with the protein concentration as low as $0.01 \mathrm{mM}$. The protein HOS properties of folding, intermediate exchange and oligomerization were all reflected in the NMR spectral patterns. Using rituximab DPs, the proposed $\mathrm{D}_{\mathrm{M}}$ similarity metric was verified again. Using insulin glargine DPs, the methyl peak profile method showed that both chemical shift and relative peak height can be used to derive practically achievable similarity metrics. Finally, the sensitive ${ }^{1} \mathrm{H}^{-15} \mathrm{~N}$ sofast HMQC experiment was demonstrated to be a valuable NMR method to characterize the protein backbone HOS.

\section{Results}

The peptide and protein drug products (DPs) listed in Table 1 were sourced from the US market except Reditux ${ }^{\circledR}$, which was sourced from India. All DPs are the reference drugs except Basaglar ${ }^{\circledR}$ and Reditux ${ }^{\circledR}$, which are follow-on products to Lantus ${ }^{\circledR}$ and Rituxan ${ }^{\circledR}$, respectively. All $1 \mathrm{D}{ }^{1} \mathrm{H}, 2 \mathrm{D}^{1} \mathrm{H}-{ }^{13} \mathrm{C}$ and $2 \mathrm{D}^{1} \mathrm{H}-{ }^{15} \mathrm{~N}$ NMR spectra were collected on formulated DPs with minimal dilution of adding $5 \% \mathrm{D}_{2} \mathrm{O}(v / v)$. 
Table 1. Drug Products studied.

\begin{tabular}{|c|c|c|c|c|c|}
\hline Drug Product & Drug Substance & Number of Amino Acids & M.W. (kDa) & Concentration (mM) & $\mathrm{pH}$ \\
\hline Miacalcin ${ }^{\circledR}$ & Calcitonin-Salmon & 32 & 3.43 & $0.0097^{1}$ & $\mathrm{n} / \mathrm{a}$ \\
\hline Saxenda ${ }^{\circledR}$ & Liraglutide & 38 & 3.75 & 1.6 & 8.15 \\
\hline Forteo $^{\circledR}$ & Teriparatide & 34 & 4.12 & 0.061 & 4 \\
\hline Byetta $^{\circledR}$ & Exenatide & 39 & 4.19 & 0.060 & 4.5 \\
\hline HumulinR ${ }^{\circledR}$ & Insulin Human & 51 & 5.81 & $0.60^{2}$ & $\mathrm{n} / \mathrm{a}$ \\
\hline Humalog ${ }^{\circledR}$ & Insulin Lispro & 51 & 5.81 & $0.60^{2}$ & $7.0-7.8$ \\
\hline Lantus ${ }^{\circledR}$ Basaglar ${ }^{\circledR}$ & Insulin Glargine & 53 & 6.06 & 0.60 & 4 \\
\hline Rituxan ${ }^{\circledR}$ Reditux ${ }^{\circledR}$ & Rituximab & 1328 & 145 & 0.069 & 6.5 \\
\hline
\end{tabular}

${ }^{1}$ Based on the equivalence between $1 \mathrm{mg}$ and 6000 I.U. per USP NF.; ${ }^{2}$ based on the equivalence between $0.0347 \mathrm{mg}$ and 1 USP unit per USP NF and Eu. Pharm.; n/a: not available from the drug label.

\section{1. $1 D^{1} H$ NMR Spectroscopy}

\subsubsection{Excipients}

Excipients in protein formulations can function as preservatives (e.g., phenol and $m$-cresol), tonicity agents (e.g., mannitol), $\mathrm{pH}$ buffering agents (e.g., acetate) or protein stabilizers (e.g., polysorbate 80) [28]. The excipients are mostly small molecules at high concentration relative to the API. Due to the fast tumbling of excipients in liquid formulations, excipient peaks generally were sharper and more intense in the NMR spectra (Figure 1, left panels). Most excipient peaks were located in the high field region between 1 and $4 \mathrm{ppm}$, while preservatives with aromatic moieties had peaks between 6.5 and $7.5 \mathrm{ppm}$. The peaks were readily assignable with the help of chemical shift databases $[29,30]$ or $2 \mathrm{D}$ ${ }^{1} \mathrm{H}-{ }^{13} \mathrm{C}$ spectra. The excipient polysorbate 80 (PS80) had a more complicated spectrum, with major peaks at 3.7, 2.3, 2.0, 1.6, 1.3 and 0.9 ppm [31]. Importantly, all excipient peaks should be excluded when protein HOS comparison is performed.

\subsubsection{Process-Related Impurities}

Small sharp peaks from process related impurities such as residual solvents and leachable were also identified and should be blinded out of HOS comparison as well [32,33]. For example, silicone oil used as a lubricant in DP containers could leach into the formulation and appear as a broad peak of polydimethylsiloxane (s) at $0.05 \mathrm{ppm}$, which can be further hydrolyzed to dimethylsilanediol and trimethylsilanol and appears as sharp peaks at $0.15 \mathrm{ppm}(\mathrm{d})$ and $0.13 \mathrm{ppm}(\mathrm{t})$, respectively (Figure 1A,C,D, right panels) [34] Notably, the proton resonances of larger proteins could overlap with the spectral region around $0 \mathrm{ppm}$. Therefore, if NMR is used for the quantification of silicone oil components in protein formulations, $\mathrm{T}_{2}$-filtered CPMG pulse train may be used to remove protein resonances $[35,36]$.

\subsubsection{Protein HOS}

The protein DS may be formulated at concentration of about $1 \mathrm{mM}$ or less (Table 1). The $1 \mathrm{D}^{1} \mathrm{H}$ NMR spectrum is the most sensitive NMR method to characterize protein HOS in DP formulations. The spectra need to be vertically enlarged by $2-4$ orders of magnitude in order to visualize the lower intensity protein peaks (Figure 1, right panels). Among the tested DPs, the $3.43 \mathrm{kDa}$ calcitonin-salmon is formulated at the lowest concentration of $9.7 \mu \mathrm{M}$. Calcitonin's sharp and dispersed amide peaks suggested that calcitonin-salmon adopts a folded monomeric HOS in formulation (Figure 1A). The $3.75 \mathrm{kDa}$ liraglutide has a similar M.W. to calcitonin-salmon, however, broadened amide peaks were observed in liraglutide's spectra (Figure 1B), suggesting oligomerization of the protein in formulation. 

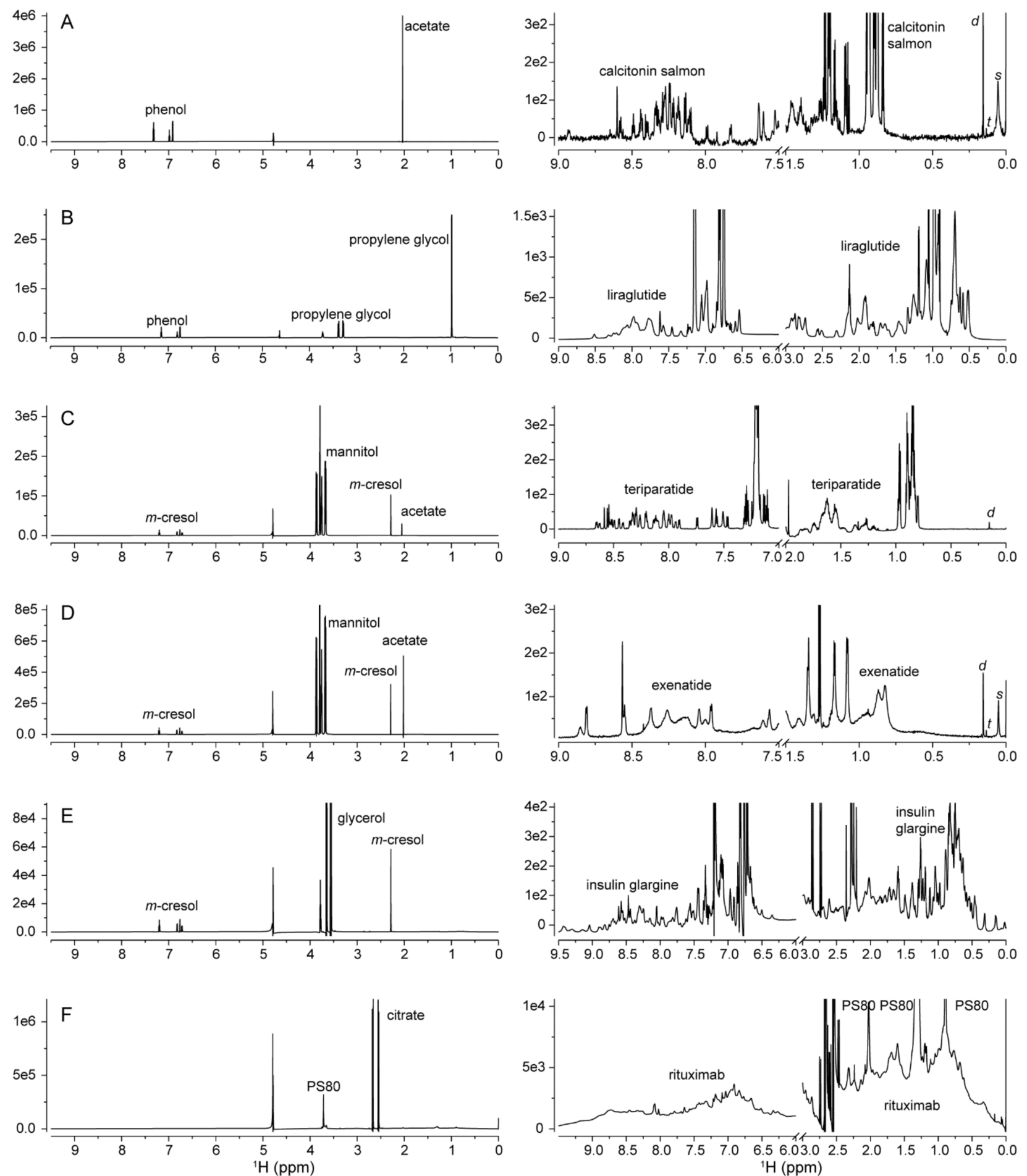

Figure 1. The $1 \mathrm{D}^{1} \mathrm{H}$ NMR spectra of protein drug products of Miacalcin ${ }^{\circledR}(\mathbf{A})$, Saxenda ${ }^{\circledR}\left(\right.$ B), Forteo ${ }^{\circledR}(\mathbf{C})$, Byetta ${ }^{\circledR}(\mathbf{D})$, Lantus $^{\circledR}(\mathrm{E})$ and Rituxan ${ }^{\circledR}(\mathrm{F})$ collected using an $850 \mathrm{MHz}$ spectrometer. The spectra on the left are in full scale and those on the right are vertically enlarged and horizontally cut to display protein peaks. Signals from major excipients, drug substances and the leachable compounds dimethylsilanediol (d), trimethylsilanol (t) and polydimethylsiloxane (s) are annotated. 
The 4.12 kDa teriparatide had sharp and dispersed amide peaks, suggesting a folded HOS in the formulation (Figure 1C). For the $4.19 \mathrm{kDa}$ exenatide, much broadened peaks were observed while the detected number of peaks was much less (Figure 1D), suggesting the peptide was undergoing intermediate exchange broadening [37]. The observed exchange broadening is associated with exenatide in equilibrium between several HOS states and the exchange kinetics occur over a similar time scale of the chemical shift difference between different states, usually in the range of $\mu s-m s$ exchange.

For the $6.06 \mathrm{kDa}$ insulin glargine, the detected dispersed peaks suggest well folded HOS in the formulation at $\mathrm{pH} 4$ (Figure 1E). Finally, the observed broadened peaks of the $145 \mathrm{kDa}$ rituximab were due to its large M.W., but the dispersed amide peaks suggest the monoclonal antibody has a folded HOS (Figure 1F).

\subsubsection{Similarity Metrics of $D_{M}$}

Although the $1 \mathrm{D}^{1} \mathrm{H}$ spectra can be used to assess protein HOS qualitatively, a quantifiable similarity metric is of interest to demonstrate comparability after manufacturing changes or similarity between any two drug brands [38]. Previously, $1 \mathrm{D}^{1} \mathrm{H}$ spectra between the reference insulin and the follow-on insulin DPs were chemometrically compared using principal component analysis (PCA) and Mahalanobis distance $\left(\mathrm{D}_{\mathrm{M}}\right)$ metrics, which were derived from PCA space [27]. The previous results on insulin DPs suggested a $D_{M}$ value of 3.3 as the similarity threshold [27], where above 3.3 value there were clear differences in the HOS, while below that there were no discernable differences. Here, the rituximab DPs Rituxan ${ }^{\circledR}$ and Reditux ${ }^{\circledR}$ were compared using the same approach. Excipient free regions of the spectra including the down field amide spectrum are informative for rituximab HOS.

The $1 \mathrm{D}^{1} \mathrm{H}$ spectra of seven lots of Rituxan ${ }^{\circledR}$ and three lots of Reditux ${ }^{\circledR}$ (Table S1) were collected using both $850 \mathrm{MHz}$ and $600 \mathrm{MHz}$ spectrometers. Representative spectra from both brands were superimposed and visually appeared similar (Figure 2, left). Spectral regions belonging to excipients, residual solvents, water and blank were excluded before PCA. The PCA results showed that the first two principal components accounted for over $70 \%$ of the spectral intensity variations (Figure 2, right). The Mahalanobis distance $\left(\mathrm{D}_{\mathrm{M}}\right)$ calculated from the first three principal components (Table S2) using Equations (1) and (2) were 1.95 and 3.15, when the $850 \mathrm{MHz}$ data and the $600 \mathrm{MHz}$ data were used, respectively. Both values were below the established similarity threshold $D_{M}$ value of 3.3 [27], suggesting similar HOS between the two products. Ninety percent $(90 \%)$ confidence interval ellipses were drawn for the Rituxan ${ }^{\circledR}$ DP lots in PC1/2 space (Figure 2, right). For the $850 \mathrm{MHz}$ data, two lots of Reditux ${ }^{\circledR}$ fell outside the ellipse; for the $600 \mathrm{MHz}$ data, one lot of Reditux ${ }^{\circledR}$ fell outside the ellipse. Therefore, the slight difference in field dependent $D_{M}$ values is not necessarily correlated to the apparent differences shown in the ellipse circles. The results suggest any $\mathrm{D}_{\mathrm{M}}$ values below the metric of 3.3 would indicate high similarity.

\section{2. $2 \mathrm{D}^{1} \mathrm{H}_{-}{ }^{13} \mathrm{C}$ Spectroscopy}

\subsubsection{Protein Specificity}

As an alternative to $1 \mathrm{D}^{1} \mathrm{H}$ spectra, $2 \mathrm{D}^{1} \mathrm{H}-{ }^{13} \mathrm{C}$ heteronuclear single quantum coherence (HSQC) spectra are highly specific to protein sequence and HOS. The HSQC spectrum of the methyl chemical shift region, which was $12-27$ ppm along the ${ }^{13} \mathrm{C}$ axis and $0-1.5 \mathrm{ppm}$ along the ${ }^{1} \mathrm{H}$ axis, has higher sensitivity due to the $3 \mathrm{C}-\mathrm{H}$ correlations and fast internal rotational dynamics of the methyl group. In addition, major excipient or solvent peaks, if observed in a methyl HSQC spectrum, can be readily identified because of their strong intensity and unique ${ }^{13} \mathrm{C}$ chemical shifts, e.g., ethanol in insulin DPs of HumulinR ${ }^{\circledR}$, Humalog ${ }^{\circledR}$ and Basaglar ${ }^{\circledR}$ (Figure 3). Therefore, methyl-HSQC spectra can be an ideal high-resolution spectrum for HOS assessment. 

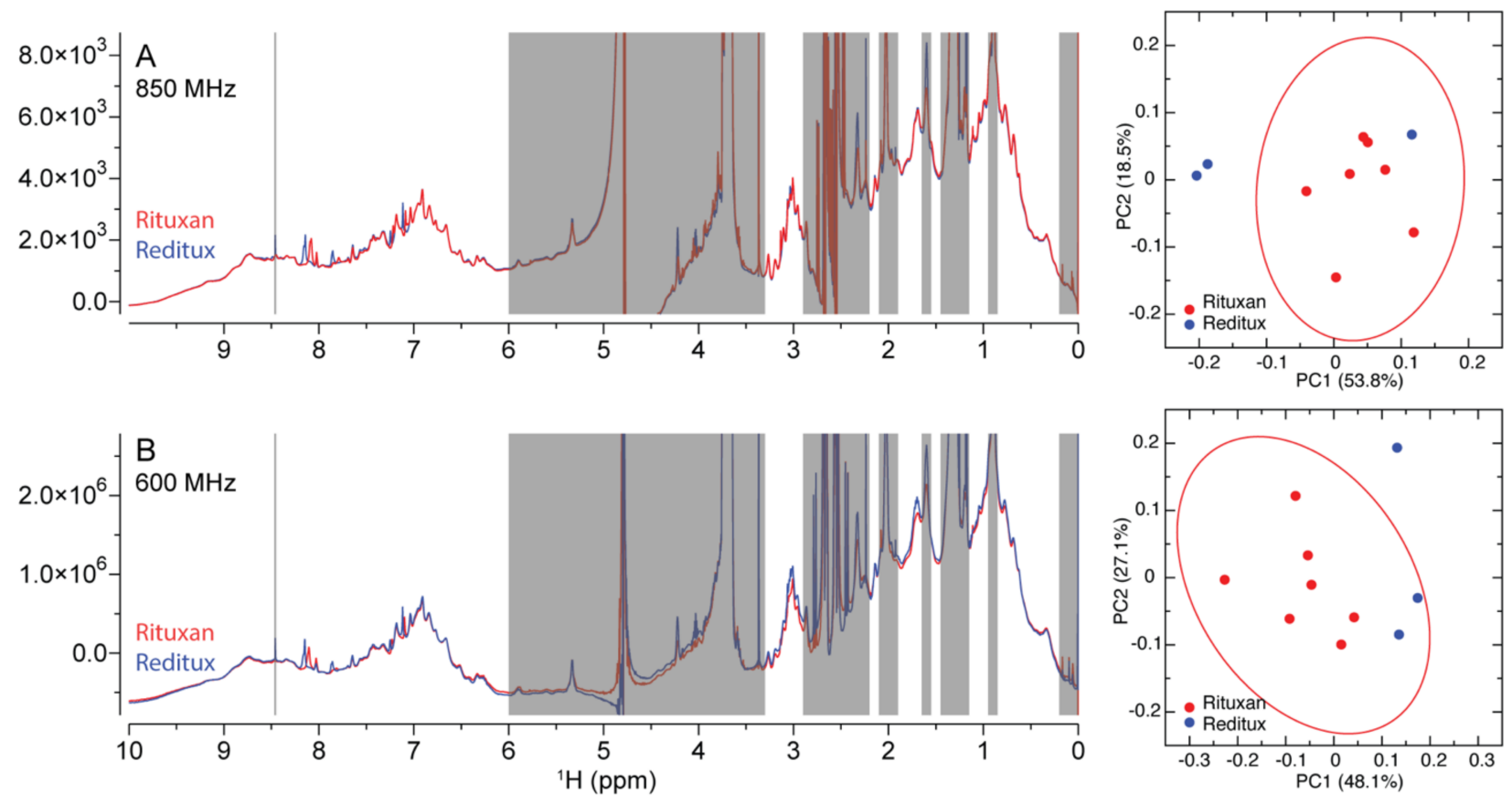

Figure 2. The superimposed $1 \mathrm{D}{ }^{1} \mathrm{H}$ NMR spectra of representative rituximab drug products (DP) of Rituxan ${ }^{\circledR}$ and Reditux ${ }^{\circledR}$ collected using $850 \mathrm{MHz}$ (A, left) and $600 \mathrm{MHz}$ (B, left) spectrometers. The spectral regions in gray of 0-0.2 ppm, 0.85-0.95 ppm, 1.15-1.45 ppm, 1.55-1.65 ppm, 1.9-2.1 ppm, 2.2-2.9 ppm, 3.3-6 ppm and 8.45-8.47 ppm were excluded before principal component analysis (PCA). The resulting PCA scores for each DP lot from both $850 \mathrm{MHz}$ data (A, right) and $600 \mathrm{MHz}$ data (B, right) were plotted along the PC1 and PC2 axes. The $90 \%$ confidence ellipses are drawn for Rituxan ${ }^{\circledR}$ lots only (A/B, right).

The amino acids possessing one or two methyl groups are Alanine (Ala), Methionine (Met), Threonine (Thr), Valine (Val), Leucine (Leu) and Isoleucine (Ile). For insulin, methyl peaks of Ala, Thr, Val, Leu and Ile observed in the DP spectra of HumulinR ${ }^{\circledR}$ and Humalog ${ }^{\circledR}$ (Table 1) can be approximately assigned by referencing the literature assignment for insulin human [39] and insulin lispro [40] (Figure 3A). Due to formulation or buffer differences, the assignment can be confidently made for residues of Ile at positions A2 and A10, Ala at position B14 and Thr at positions A8, B27 and B30; ambiguities remain for the Val and Leu clusters in the ${ }^{13} \mathrm{C}$ chemical shift ranges of $21-22 \mathrm{ppm}$ and $23-27 \mathrm{ppm}$, respectively (Figure 3A). Nevertheless, large chemical shift differences were observed between insulin human and insulin lispro, both of which have an identical M.W. of 5808 Da. The insulin lispro sequence differs from insulin human by two amino acid residues at positions B28-B29, Pro-Lys in insulin human and Lys-Pro in insulin lispro. Thus, the sequence difference introduced large changes in chemical shifts for almost every methyl peak (Figure 3A), which is consistent with a large change of HOS in the formulated API arising from only a two amino acids swap.

Shown in Figure 3B is the superimposed spectra between Lantus ${ }^{\circledR}$ and Basaglar ${ }^{\circledR}$, both of which contain the same DS insulin glargine. The chemical shift assignment was not transferrable from other insulins because the spectra are significantly different (Figure 3A,B). The methyl peaks of insulin glargine were labeled with possible amino acid type and alphabetic letters. The total number of identified peaks $(s / n>10)$ was 48 , which is more than the expected 28 methyl peaks calculated from the insulin glargine sequence. The increased peak number is attributed to some of the methyl groups adopting at least two slow exchange conformations in the formulation, e.g., Ala(B14) had two peaks of Ala-a and Ala-b at ${ }^{13} \mathrm{C}$ chemical shift of $19 \mathrm{ppm}$ (Figure 3B). Overall, the methyl HSQC spectra between the two DPs are highly similar, suggesting that insulin glargine is folded in similar HOS for the two formulations. 

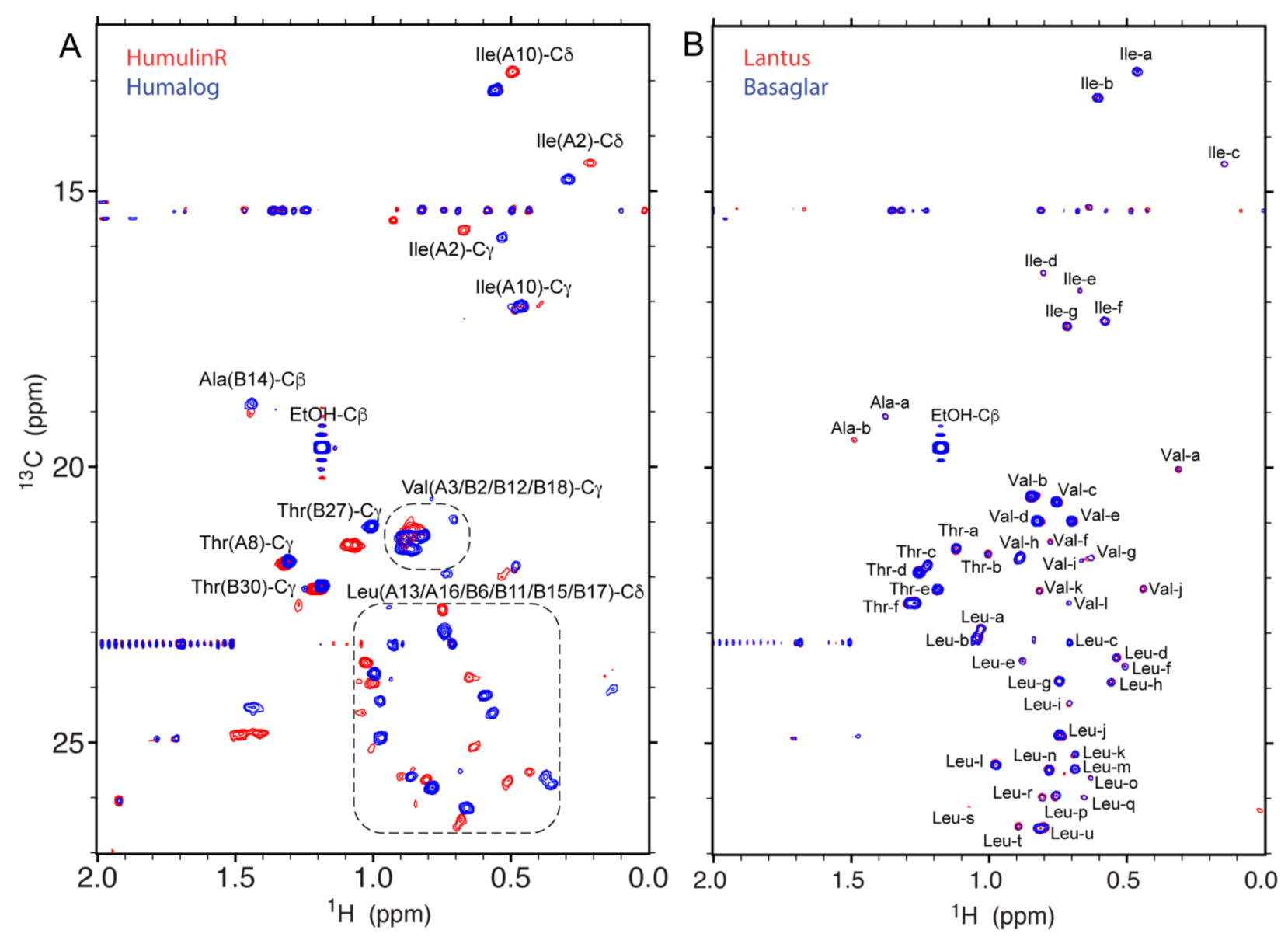

Figure 3. The superimposed $2 \mathrm{D}^{1} \mathrm{H}^{13} \mathrm{C}$ HSQC NMR spectra between insulin drug products of HumulinR ${ }^{\circledR}$ and $\mathrm{Humalog}^{\circledR}$ (A) and between Lantus ${ }^{\circledR}$ and Basaglar ${ }^{\circledR}$ (B) collected using a $600 \mathrm{MHz}$ spectrometer. The plotting threshold of intensity was at a signal to noise ratio of 5 and 10 for $(\mathbf{A})$ and (B), respectively. The methyl spectra of insulin human and insulin lispro were approximately assigned according to the published assignments; ambiguities were observed in the Valine and Leucine clusters shown in dashed boxes (A). The spectra of insulin glargine cannot be definitively assigned due to a large change in the observed chemical shifts and each peak was labeled for possible amino acid type and with an alphabetic letter (B).

\subsubsection{Similarity Metrics of $\Delta \delta$}

Each peak in a $2 \mathrm{D}{ }^{1} \mathrm{H}_{-}{ }^{13} \mathrm{C}$ NMR spectrum has three dimensions, including peak intensity and ${ }^{1} \mathrm{H}$ and ${ }^{13} \mathrm{C}$ chemical shifts, all of which are sensitive to protein HOS. Previous spectral comparisons on insulin [38] and filgrastim [26] 2D spectra have applied PCA for similarity evaluation, which took into account all spectral variables from the three dimensions (two frequencies and intensity) for comparison. However, no similarity metrics were derived. The filgrastim ${ }^{1} \mathrm{H}_{-}{ }^{15} \mathrm{~N}$ spectral comparison established a combined chemical shift difference (CCSD) metric of $8 \mathrm{ppb}$ [26]. The chemical shift comparison was repeated here for the 48 methyl peaks between Lantus ${ }^{\circledR}$ and Basaglar ${ }^{\circledR}$. For each brand the inter-lot averaged chemical shift values were used as DP specific $\delta$. The differences of chemical shift $(\Delta \delta)$ between the two DPs were plotted along both ${ }^{1} \mathrm{H}$ and ${ }^{13} \mathrm{C}$ axis (Figure $4 \mathrm{~A}, \mathrm{~B}$ ). The maximum ${ }^{1} \mathrm{H} \Delta \delta$ was $3.4 \mathrm{ppb}$ identified in the Leu-d peak. The maximum ${ }^{13} \mathrm{C} \Delta \delta$ was $-13 \mathrm{ppb}$ identified in the Leu-j peak. When a 10\% larger difference is permitted in the maximum $\Delta \delta$, similarity metrics with rounded values of 4 and $15 \mathrm{ppb}$ for the ${ }^{1} \mathrm{H}$ and ${ }^{13} \mathrm{C}$ chemical shifts, respectively, can be proposed. These metrics are on par with the previous CCSD metric of $8 \mathrm{ppb}$ [26] or $4 \mathrm{ppb}$ [41], which was a normalized $\Delta \delta$ value from both the ${ }^{1} \mathrm{H}$ and ${ }^{15} \mathrm{~N}$ axes. 

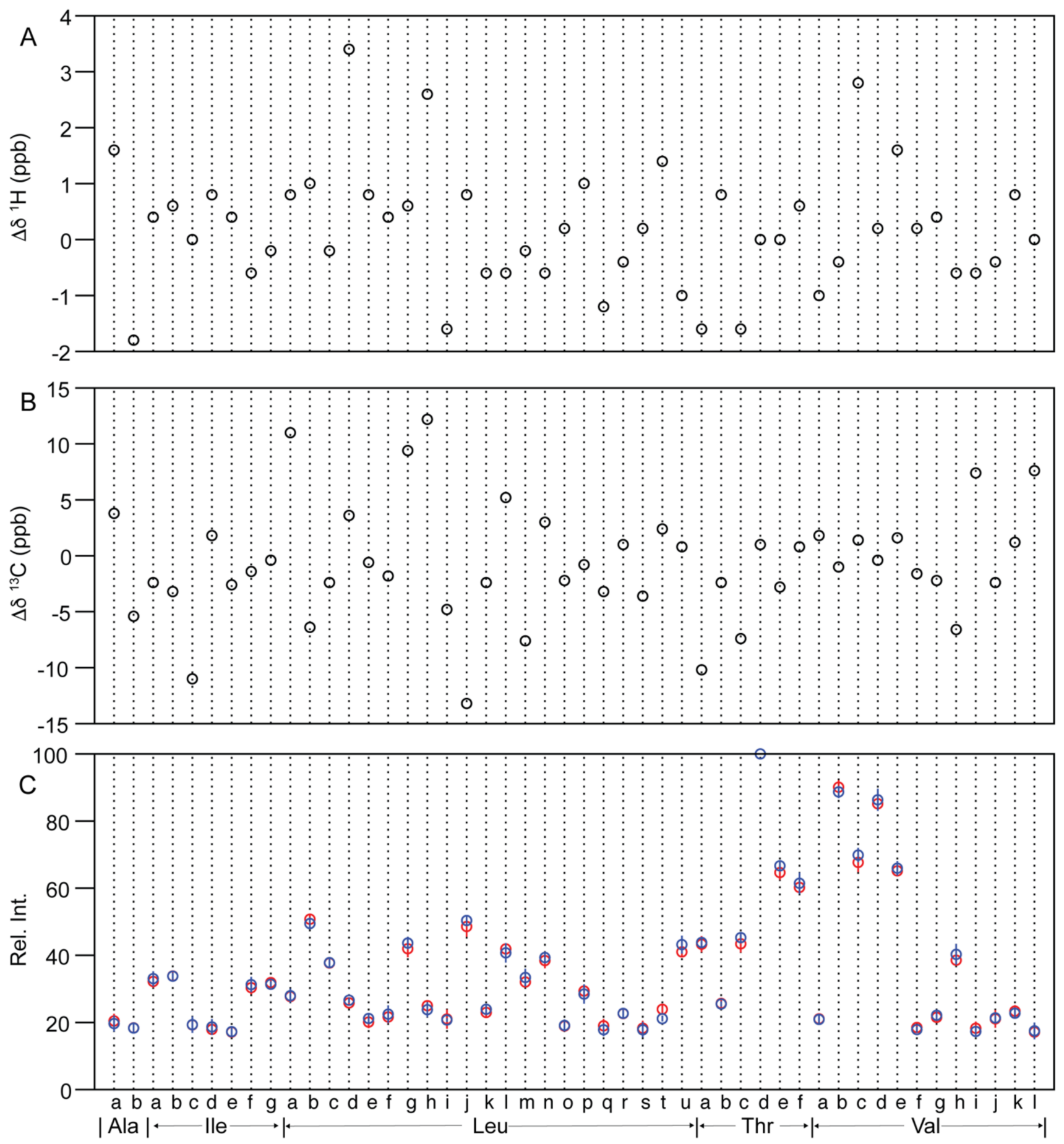

Figure 4. The chemical shift and relative peak height difference between insulin glargine drug products of Lantus ${ }^{\circledR}$ and Basaglar ${ }^{\circledR}$. The ${ }^{1} \mathrm{H}(\mathbf{A})$ and ${ }^{13} \mathrm{C}(\mathbf{B})$ chemical shift difference and the relative peak heights $(\mathbf{C})$ were plotted along the labeled peaks of Figure 3B. 


\subsubsection{Methyl Peak Profile}

The peak intensity was compared using peak heights. First, the absolute peak heights of the strongest peak, Thr-d, were tabulated for five lots of each brand and five technical repeats from one lot of Lantus ${ }^{\circledR}$ (Table S3). The calculated $p$ value between the five technical repeats and the five lots of Lantus ${ }^{\circledR}$ was 0.35 , demonstrating the technical issues related to the spectral differences were within the inter-lot DP differences. By contrast, the Thr-d peak height in Lantus ${ }^{\circledR}$ inter-lot spectra was on average $4 \%$ higher than the peak height of the Basaglar ${ }^{\circledR}$ inter-lot spectra. The $4 \%$ difference was significant with a $p$ value of 0.0061 (Table S3), which is less than the threshold value of 0.05 . The $4 \%$ difference may be related to differences in assay and response $Q$-factor of the NMR probe to different formulations, usually related to electric capacity or ionic strength [42]. As a result, the comparison using absolute peak height for all methyl peaks was deemed not suitable.

However, the relative peak heights, related to the dynamics and exchange kinetics of each methyl group should still be a valid choice for comparison purposes. Here, the ratios of each peak height to the Thr-d were calculated according to Equation (3). The mean and standard deviation from both Lantus ${ }^{\circledR}$ inter-lot spectra and Basaglar ${ }^{\circledR}$ inter-lot spectra were plotted in Figure 4C. The $p$ values were calculated for all 48 peaks (Table 2) and $47 p$ values were higher than 0.05 except for the Leu-t peak with $p$ value of 0.0055 . Ultimately, 47 out of 48 peaks were equivalent in relative peak height between the two brands, demonstrating that the HOS distribution and exchange kinetics of the insulin glargine in the two DPs were similar. The work suggested the similarity metrics for peaks that show comparable relative peak height could be at least $98 \%(47 / 48)$.

\section{3. $2 D^{1} H_{-}{ }^{15} \mathrm{~N}$ Spectroscopy}

The $2 \mathrm{D}^{1} \mathrm{H}_{-}-{ }^{15} \mathrm{~N}$ spectrum may be a more specific NMR experiment than ${ }^{1} \mathrm{H}_{-}{ }^{13} \mathrm{C}$ HSQC to evaluate protein HOS because the amide ${ }^{1} \mathrm{H}$ and ${ }^{15} \mathrm{~N}$ chemical shifts are exclusively sensitive to peptide backbone conformation. However, the ${ }^{1} \mathrm{H}-{ }^{15} \mathrm{~N}$ HSQC experiment is at least one order of magnitude less sensitive than the methyl ${ }^{1} \mathrm{H}^{-13} \mathrm{C}$ HSQC experiment. Thus, ${ }^{15} \mathrm{~N}$ spectra via indirect detection in formulated DP samples can be challenging to collect when the DS concentration is less than $1 \mathrm{mM}$. The previously developed NMR pulse sequence of sofast-heteronuclear multi-quantum correlation (HMQC) has the advantage of shorter recycle delay without perturbing water resonances [43]. The sofast-HMQC experiment allows the $2 \mathrm{D}^{1} \mathrm{H}_{-}{ }^{15} \mathrm{~N}$ correlation spectrum to be collected within $24 \mathrm{~h}$ for DPs with protein concentrations as low as $0.06 \mathrm{mM}$. Representative spectra of Forteo ${ }^{\circledR}$, Byetta ${ }^{\circledR}$ and Lantus ${ }^{\circledR}$ are shown in Figure 5. Amide peaks of the protein backbone and Asn/Gln side chains are observed in the ${ }^{15} \mathrm{~N}$ chemical shift range of $108-129 \mathrm{ppm}$ and the ${ }^{1} \mathrm{H}$ chemical shift range of 7.4-9.1 ppm. The number of detected peaks for teriparatide in Forteo ${ }^{\circledR}$ was 29 (Figure 5A), while a total of 44 peaks are expected. The $66 \%$ coverage suggests the teriparatide adopts a well-defined HOS in the formulation, which is consistent with the 1D ${ }^{1} \mathrm{H}$ spectral pattern (Figure 1C). By contrast, only six peaks were detected for exenatide in Byetta $^{\circledR}$ (Figure 5B), whereas a total of 39 peaks are expected. The $15 \%$ coverage suggests the exenatide resonances are in intermediate exchange between different HOS forms, which is, again, consistent with the broadening in the $1 \mathrm{D}^{1} \mathrm{H}$ spectrum (Figure 1D). For insulin glargine in Lantus ${ }^{\circledR}$, the 54 peaks detected account for $87 \%$ of the expected 62 peaks (Figure 5C). The results for insulin glargine suggest the existence of a single or fast averaged backbone HOS in the formulation. 
Table 2. The relative peak height comparison of insulin glargine DPs.

\begin{tabular}{|c|c|c|c|c|c|c|c|c|c|c|c|}
\hline \multirow{2}{*}{ Peak } & \multicolumn{5}{|c|}{ Antus $^{\circledR}$} & \multicolumn{5}{|c|}{ Basaglar $^{\circledR}$} & \multirow{2}{*}{$p$ Value } \\
\hline & Lot 1 & Lot 2 & Lot 3 & Lot 4 & Lot 5 & Lot 1 & Lot 2 & Lot 3 & Lot 4 & Lot 5 & \\
\hline Ala-a & 17.5 & 20.7 & 19.8 & 20.8 & 23.4 & 20.2 & 17.0 & 22.7 & 20.8 & 17.6 & 0.61 \\
\hline Ala-b & 18.0 & 19.0 & 17.4 & 18.1 & 19.5 & 16.3 & 18.8 & 17.3 & 18.7 & 20.7 & 0.96 \\
\hline Ile-a & 30.2 & 34.7 & 32.7 & 30.6 & 32.8 & 34.5 & 33.2 & 29.6 & 35.5 & 32.4 & 0.54 \\
\hline Ile-b & 35.3 & 34.5 & 33.6 & 32.5 & 33.3 & 34.9 & 34.3 & 32.2 & 34.1 & 33.3 & 0.92 \\
\hline Ile-c & 20.1 & 21.9 & 19.2 & 17.8 & 17.4 & 20.9 & 21.1 & 15.5 & 18.3 & 21.0 & 0.96 \\
\hline Ile-d & 20.0 & 16.8 & 17.8 & 16.9 & 18.0 & 19.8 & 20.8 & 17.2 & 15.2 & 20.2 & 0.57 \\
\hline Ile-e & 16.9 & 15.9 & 16.4 & 17.3 & 19.2 & 19.3 & 15.7 & 16.5 & 16.7 & 17.9 & 0.93 \\
\hline Ile-f & 29.8 & 32.3 & 27.4 & 30.4 & 31.9 & 30.6 & 31.4 & 35.0 & 28.7 & 30.7 & 0.52 \\
\hline Ile-g & 32.0 & 31.4 & 30.6 & 30.9 & 34.6 & 31.0 & 32.6 & 31.8 & 31.0 & 30.4 & 0.54 \\
\hline Leu-a & 27.6 & 26.4 & 26.7 & 27.2 & 30.7 & 29.1 & 27.9 & 25.4 & 26.6 & 30.8 & 0.84 \\
\hline Leu-b & 52.8 & 52.0 & 48.8 & 49.4 & 50.7 & 50.9 & 49.3 & 50.3 & 46.5 & 50.3 & 0.28 \\
\hline Leu-c & 36.9 & 37.6 & 36.3 & 39.3 & 38.4 & 39.9 & 35.9 & 38.0 & 38.3 & 37.2 & 0.88 \\
\hline Leu-d & 25.7 & 25.9 & 26.7 & 24.8 & 25.8 & 26.6 & 25.3 & 27.0 & 27.0 & 27.2 & 0.11 \\
\hline Leu-e & 22.0 & 17.7 & 18.8 & 20.9 & 21.1 & 23.4 & 20.9 & 22.3 & 19.4 & 20.0 & 0.35 \\
\hline Leu-f & 22.5 & 18.8 & 21.6 & 21.2 & 24.0 & 23.6 & 25.7 & 22.1 & 18.5 & 22.3 & 0.58 \\
\hline Leu-g & 41.1 & 41.1 & 39.6 & 41.7 & 46.2 & 44.7 & 43.6 & 43.5 & 40.8 & 45.7 & 0.26 \\
\hline Leu-h & 23.3 & 26.6 & 23.6 & 25.6 & 25.8 & 25.9 & 24.6 & 21.2 & 21.6 & 25.7 & 0.35 \\
\hline Leu-i & 20.1 & 22.2 & 16.9 & 21.1 & 24.8 & 21.3 & 21.0 & 21.1 & 20.2 & 19.9 & 0.83 \\
\hline Leu-j & 46.4 & 50.1 & 44.5 & 49.9 & 52.0 & 51.8 & 50.8 & 48.3 & 49.6 & 51.1 & 0.28 \\
\hline Leu-k & 21.7 & 25.4 & 21.7 & 23.1 & 23.0 & 26.2 & 22.1 & 23.7 & 24.9 & 22.6 & 0.38 \\
\hline Leu-1 & 42.4 & 41.8 & 41.6 & 41.3 & 42.3 & 43.9 & 41.4 & 37.5 & 38.0 & 42.9 & 0.43 \\
\hline Leu-m & 31.2 & 31.0 & 32.7 & 31.2 & 33.9 & 34.2 & 34.6 & 29.1 & 32.9 & 36.0 & 0.34 \\
\hline Leu-n & 36.2 & 38.2 & 37.2 & 38.4 & 42.3 & 40.8 & 37.6 & 37.3 & 40.5 & 40.5 & 0.52 \\
\hline Leu-o & 18.1 & 17.6 & 18.8 & 21.4 & 18.5 & 18.8 & 17.3 & 20.2 & 21.6 & 17.7 & 0.85 \\
\hline Leu-p & 30.6 & 30.6 & 29.4 & 28.0 & 28.1 & 31.7 & 28.7 & 24.7 & 26.4 & 30.8 & 0.57 \\
\hline Leu-q & 19.1 & 21.8 & 19.7 & 16.1 & 18.3 & 18.6 & 19.9 & 15.1 & 16.7 & 18.7 & 0.38 \\
\hline Leu-r & 24.2 & 22.7 & 23.0 & 21.9 & 21.5 & 22.6 & 24.7 & 23.5 & 20.5 & 22.2 & 0.96 \\
\hline Leu-s & 15.3 & 19.1 & 18.4 & 17.3 & 21.4 & 15.7 & 17.9 & 15.6 & 18.9 & 21.0 & 0.75 \\
\hline Leu-t & 23.0 & 25.3 & 23.7 & 25.3 & 22.4 & 21.7 & 21.5 & 21.6 & 19.6 & 21.3 & 0.0055 \\
\hline Leu-u & 42.5 & 38.8 & 40.1 & 41.6 & 42.2 & 43.2 & 40.2 & 42.2 & 42.8 & 47.5 & 0.17 \\
\hline Thr-a & 45.8 & 45.8 & 41.2 & 40.9 & 42.8 & 43.8 & 41.9 & 44.8 & 42.4 & 46.0 & 0.73 \\
\hline Thr-b & 27.2 & 27.0 & 24.0 & 25.0 & 25.0 & 24.1 & 25.8 & 26.1 & 25.9 & 25.5 & 0.83 \\
\hline Thr-c & 39.4 & 45.2 & 42.5 & 43.8 & 46.1 & 45.9 & 44.2 & 47.3 & 44.7 & 44.3 & 0.21 \\
\hline Thr-d & 100 & 100 & 100 & 100 & 100 & 100 & 100 & 100 & 100 & 100 & $\mathrm{n} / \mathrm{a}$ \\
\hline Thr-e & 64.0 & 65.5 & 61.5 & 64.8 & 67.4 & 68.5 & 68.0 & 64.5 & 65.5 & 66.9 & 0.13 \\
\hline Thr-f & 60.2 & 61.1 & 59.0 & 58.8 & 61.9 & 65.1 & 64.5 & 58.8 & 58.1 & 60.7 & 0.46 \\
\hline Val-a & 22.5 & 21.6 & 22.1 & 19.1 & 20.0 & 22.3 & 21.7 & 18.7 & 20.6 & 21.3 & 0.85 \\
\hline Val-b & 92.1 & 91.1 & 87.1 & 88.6 & 91.4 & 91.2 & 86.6 & 87.4 & 88.4 & 89.6 & 0.29 \\
\hline Val-c & 67.2 & 65.7 & 64.6 & 68.9 & 71.8 & 73.0 & 70.7 & 67.1 & 69.2 & 69.6 & 0.2 \\
\hline Val-d & 84.8 & 84.8 & 82.9 & 87.1 & 86.3 & 89.3 & 90.4 & 83.1 & 85.1 & 83.9 & 0.5 \\
\hline Val-e & 64.2 & 65.2 & 63.6 & 67.1 & 65.6 & 68.1 & 67.2 & 62.5 & 66.4 & 65.3 & 0.52 \\
\hline Val-f & 20.0 & 17.8 & 19.3 & 18.0 & 17.4 & 18.4 & 17.2 & 17.3 & 19.2 & 17.2 & 0.34 \\
\hline Val-g & 20.9 & 20.2 & 21.8 & 21.3 & 23.5 & 20.9 & 21.6 & 21.1 & 22.1 & 25.1 & 0.52 \\
\hline Val-h & 40.0 & 37.7 & 37.8 & 37.6 & 39.6 & 43.3 & 36.4 & 40.0 & 38.3 & 43.3 & 0.29 \\
\hline Val-i & 15.9 & 20.7 & 17.5 & 17.3 & 20.0 & 18.1 & 19.3 & 16.4 & 15.4 & 17.4 & 0.42 \\
\hline Val-j & 24.0 & 20.8 & 21.9 & 16.8 & 21.7 & 22.9 & 23.2 & 20.9 & 20.3 & 19.4 & 0.83 \\
\hline Val-k & 24.2 & 21.1 & 25.7 & 22.8 & 23.0 & 21.5 & 21.9 & 24.0 & 24.3 & 22.0 & 0.55 \\
\hline Val-1 & 15.8 & 19.9 & 14.5 & 17.9 & 17.7 & 20.2 & 13.5 & 17.1 & 18.6 & 18.0 & 0.84 \\
\hline
\end{tabular}



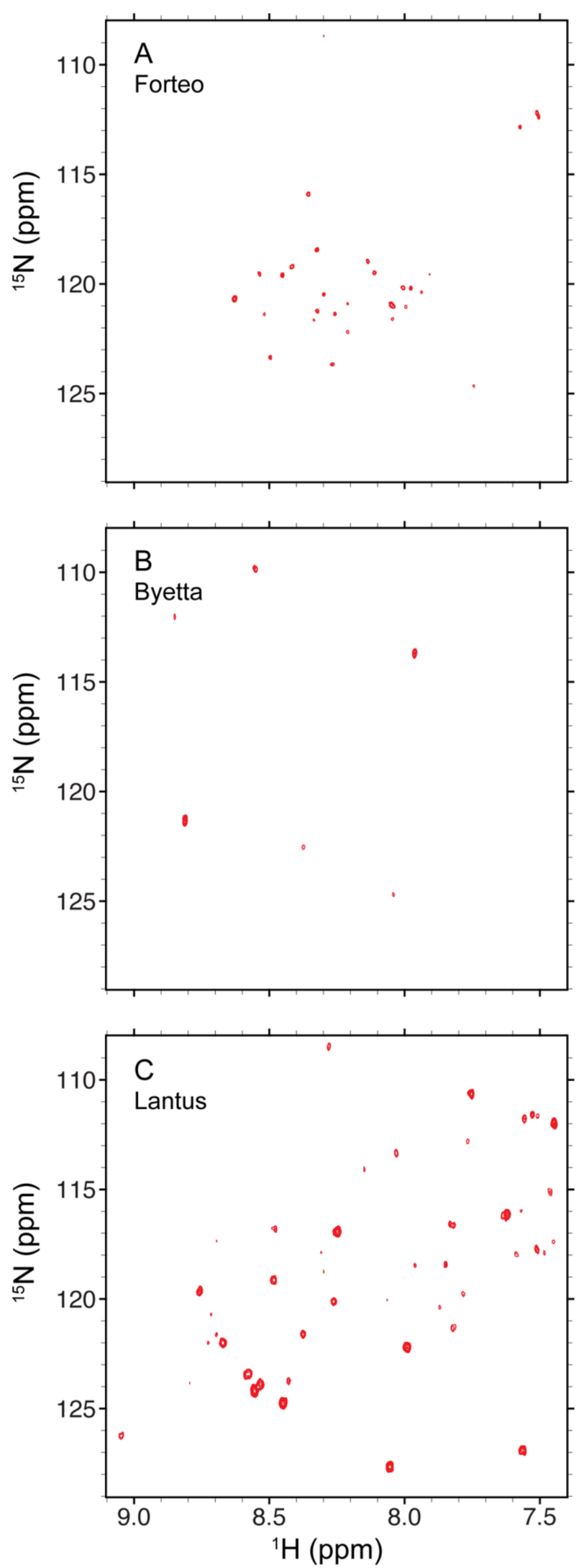

Figure 5. The $2 \mathrm{D}$ sofast ${ }^{1} \mathrm{H}_{-}{ }^{15} \mathrm{~N}$ HMQC NMR spectra of teriparatide in Forteo ${ }^{\circledR}$ (A), exenatide in Byetta $^{\circledR}(\mathbf{B})$ and insulin glargine in Lantus ${ }^{\circledR}(\mathbf{C})$ collected using an $850 \mathrm{MHz}$ spectrometer. The plotting threshold of intensity was at a signal to noise ratio of 5 . 


\section{Materials and Methods}

\subsection{Drug Product NMR Samples}

All the drug products (DP) listed in Table 1 were sourced from the US market except Reditux ${ }^{\circledR}$, which was sourced from the India market. The DPs used for similarity metrics calculations were 7 lots of Rituxan ${ }^{\circledR}, 3$ lots of Reditux ${ }^{\circledR}, 5$ lots of Lantus ${ }^{\circledR}$ and 5 lots of Basaglar $^{\circledR}$ (Table S1). NMR samples were prepared by directly mixing $0.5 \mathrm{~mL}$ of DP formulation with $0.03 \mathrm{~mL}$ of deuterium oxide, which contained $0.002 \%$ of trimethylsilylpropanoic acid (TMSP) or trimethylsilylpropanesulfonate sodium (DSS), then transferring to a $5 \mathrm{~mm}$ NMR precision tube (Wilmad-LabGlass).

\subsection{NMR Spectrsocopy}

All the NMR spectra were collected at experimental temperature of $25^{\circ} \mathrm{C}$. The NMR spectrometers were either a Bruker (Billerica, MA, USA) $850 \mathrm{MHz}$ equipped with a cryogenic QCI probe or a Bruker $600 \mathrm{MHz}$ equipped with a liquid nitrogen-cooled prodigy TCI probe.

\subsection{1. $1 \mathrm{D}^{1} \mathrm{H}$ NMR Spectra Collection and Processing}

The $1 \mathrm{D}^{1} \mathrm{H}$ NMR spectra shown in Figures 1 and 2A were collected using an $850 \mathrm{MHz}$ spectrometer. The pulse program $p 3919 g p$ was applied. The ${ }^{1} \mathrm{H}$ carrier was placed on the water resonance at $4.8 \mathrm{ppm}$. The spectral width was $14 \mathrm{ppm}$ and a total of 23,808 complex points were collected. The acquisition time was $1 \mathrm{~s}$ and recycle delay was $2 \mathrm{~s}$. The number of scans were 1024 for calcitonin-salmon and rituximab DPs, 256 for exenatide DP and 128 for liraglutide, teriparatide and insulin glargine DPs. Each free induction decay (FID) was apodized with a $90^{\circ}$ shifted sine-square window function, scaled half for the first point, zero-order phase corrected and zero filled to a spectral size of $32 \mathrm{k}$ points before Fourier transform (FT). A baseline correction method of splines was applied for the calcitoninsalmon and teriparatide spectra and no correction was applied for the liraglutide, exenatide, insulin glargine and rituximab spectra. All the 1D NMR data were processed and analyzed using MestReNova 14.1 software (Mestrelab Research S.L.).

The $1 \mathrm{D}^{1} \mathrm{H}$ NMR spectra shown in Figure 2B were collected using a $600 \mathrm{MHz}$ spectrometer. The pulse program of modified 1D NOESY noe-p3919.kc was applied [20]. The ${ }^{1} \mathrm{H}$ carrier was placed on the water resonance at $4.8 \mathrm{ppm}$. The spectral width was $13 \mathrm{ppm}$ and a total of 16,384 complex points were collected. The acquisition time was $1 \mathrm{~s}$ and the recycle delay was $2 \mathrm{~s}$. The NOE mixing time was $0.1 \mathrm{~s}$. The number of scans was 1024 . The NMR samples and data processing were identical to that used for the $850 \mathrm{MHz}$ spectra.

\subsection{2. $2 \mathrm{D}^{1} \mathrm{H}-{ }^{13} \mathrm{C}$ NMR Spectra Collection and Processing}

The $2 \mathrm{D}^{1} \mathrm{H}^{-13} \mathrm{C}$ HSQC spectra shown in Figure 3 were collected using a $600 \mathrm{MHz}$ spectrometer. A modified sensitivity enhanced gradient HSQC pulse sequence hsqcetgpsi2.kc was applied [44]. The spectral width for the ${ }^{1} \mathrm{H}$ dimension was $11 \mathrm{ppm}$ with the carrier frequency centered at $4.8 \mathrm{ppm}$. The spectral width for the ${ }^{13} \mathrm{C}$ dimension was $50 \mathrm{ppm}$ with the carrier frequency centered at $23 \mathrm{ppm}$. The complex points of 1024 and 600 were acquired for the ${ }^{1} \mathrm{H}$ and ${ }^{13} \mathrm{C}$ dimensions, respectively. The resulting acquisition times for ${ }^{1} \mathrm{H}$ and ${ }^{13} \mathrm{C}$ spins were 78 and $40 \mathrm{~ms}$, respectively. The ${ }^{13} \mathrm{C}$ decoupling sequence was GARP with a radio frequency field strength of $1.9 \mathrm{kHz}$. The coupling constant ${ }^{1} \mathrm{~J}_{\mathrm{HC}}$ was set to $155 \mathrm{~Hz}$ as a compromise between efficient INEPT transfer and $\mathrm{T}_{2}$ signal loss. The recycle delay was $2 \mathrm{~s}$. The number of scans was 16 and the total experimental time was $6 \mathrm{~h}$.

The data processing was performed using NMRPipe [45]. The apodization function of cosine was applied to both dimensions of ${ }^{1} \mathrm{H}$ and ${ }^{13} \mathrm{C}$. The first point was scaled with a factor of 0.5 before zero-order phase correction. Zero filling of $2048 \times 1024$ real data points was applied to the ${ }^{1} \mathrm{H}$ and ${ }^{13} \mathrm{C}$ dimensions. The baseline corrections on frequency domains were carried out with a polynomial function under auto mode. The chemical shift reference followed the established procedure [46]. HSQC peaks with $s / n$ higher than 10 were picked and peak heights were recorded using Sparky (Sparky 3, UCSF). 


\subsection{3. $2 \mathrm{D}^{1} \mathrm{H}-{ }^{15} \mathrm{~N}$ NMR Spectra Collection and Processing}

The sofast $2 \mathrm{D}^{1} \mathrm{H}^{15} \mathrm{~N}$ HMQC spectra shown in Figure 5 were collected using an $850 \mathrm{MHz}$ spectrometer. The Bruker pulse sequence of sfhmqcf3gpph was applied. The spectral width for the ${ }^{1} \mathrm{H}$ dimension was $14 \mathrm{ppm}$ with the carrier frequency centered at $4.8 \mathrm{ppm}$. The spectral width for the ${ }^{15} \mathrm{~N}$ dimension was $35 \mathrm{ppm}$ with the carrier frequency centered at $117 \mathrm{ppm}$. The complex points of 1784 and 200 were acquired for the ${ }^{1} \mathrm{H}$ and ${ }^{15} \mathrm{~N}$ dimensions, respectively. The resulting acquisition times for ${ }^{1} \mathrm{H}$ and ${ }^{15} \mathrm{~N}$ spins were 75 and $33 \mathrm{~ms}$, respectively. The ${ }^{15} \mathrm{~N}$ decoupling sequence was GARP with a radio frequency field strength of $1.1 \mathrm{kHz}$. The coupling constant ${ }^{1} \mathrm{~J}_{\mathrm{HN}}$ was set to $100 \mathrm{~Hz}$ as a compromise between efficient INEPT transfer and $\mathrm{T}_{2}$ signal loss. The recycle delay was $0.1 \mathrm{~s}$. The number of scans was 2000 and the total experimental time was $23 \mathrm{~h}$. The ${ }^{1} \mathrm{H}^{-15} \mathrm{~N}$ spectra were processed in a manner similar to the ${ }^{1} \mathrm{H}_{-}{ }^{13} \mathrm{C}$ spectra, except for the zero filling of $4096 \times 1024$ real data points applied to the ${ }^{1} \mathrm{H}$ and ${ }^{15} \mathrm{~N}$ dimensions.

\subsection{Calculation of Similarity Metrics}

The similarity metrics were calculated using the above processed $1 \mathrm{D}^{1} \mathrm{H}$ spectra of Rituxan ${ }^{\circledR}$ and Reditux ${ }^{\circledR}$ and $2 \mathrm{D}^{1} \mathrm{H}^{-13} \mathrm{C}$ spectra of Lantus ${ }^{\circledR}$ and Basaglar ${ }^{\circledR}$.

\subsubsection{Mahalanobis Distance $\left(\mathrm{D}_{\mathrm{M}}\right)$ between $1 \mathrm{D}$ Spectra}

The $1 \mathrm{D}^{1} \mathrm{H}$ NMR spectra of Rituxan ${ }^{\circledR}$ and Reditux ${ }^{\circledR}$ were used to calculate Mahalanobis distance [47]. The procedure was described previously [27]. Briefly, principal component analysis (PCA) was performed on the spectra of 7 lots of Rituxan ${ }^{\circledR}$ and 3 lots of Reditux ${ }^{\circledR}$. The spectral regions corresponding to peaks of excipient and solvent were excluded, including regions of 0-0.2 ppm, 0.85-0.95 ppm, 1.15-1.45 ppm, 1.55-1.65 ppm, 1.9-2.1 ppm, 2.2-2.9 ppm, 3.3-6 ppm and 8.45-8.47. The rest of the spectra were binned at $0.01 \mathrm{ppm}$ resolution, resulting in a total of 370 bins with summed spectral intensities within each bin. The summed intensities were subject to integrity checks, sum normalization and Pareto scaling before PCA using MestReNova 14.1 (Mestrelab Research S.L.).

The Mahalanobis distances $\left(D_{M}\right)$ between the two rituximab DPs were calculated using PC1-3 scores. PCA scores from all the lots of each brand were tabulated as sample matrices of $A_{\mathrm{m} \times \mathrm{p}}$ and $B_{\mathrm{n} \times \mathrm{p}}$ for Rituxan ${ }^{\circledR}$ and Reditux ${ }^{\circledR}$, respectively, with $\mathrm{m}$ or $\mathrm{n}$ representing the number of lots and $p$ representing the number of principal components used toward $D_{M}$ calculation. In the present study, m was 7 for Rituxan ${ }^{\circledR}$, $\mathrm{n}$ was 3 for Reditux ${ }^{\circledR}$ and $p$ was 3. The mean vector $\bar{A}_{1 \times p}$ and covariance matrix $S_{\mathrm{A}, \mathrm{p} \times \mathrm{p}}$ was calculated using Rituxan ${ }^{\circledR}$ sample matrix $A_{\mathrm{m} \times \mathrm{p}}$. In parallel, the mean vector $\bar{B}_{1 \times \mathrm{p}}$ and covariance matrix $S_{\mathrm{B}, \mathrm{p} \times \mathrm{p}}$ was calculated using Reditux ${ }^{\circledR}$ sample matrix $B_{\mathrm{n} \times \mathrm{p}}$. The covariance matrices of the two were averaged per Equation (1) before calculating $D_{M}$ using Equation (2). The calculations were performed using MATLAB 9.0 (The MathWorks Inc.) and the code can be found in the Supplementary Materials.

$$
\begin{aligned}
S & =\left(\mathrm{m} S_{A}+\mathrm{n} S_{B}\right) /(\mathrm{m}+\mathrm{n}) \\
D_{M} & =\sqrt{(\bar{A}-\bar{B}) S^{-1}(\bar{A}-\bar{B}) \prime}
\end{aligned}
$$

\subsubsection{Chemical Shift Difference $(\Delta \delta)$ between $2 \mathrm{D}$ Spectra}

The $2 \mathrm{D}^{1} \mathrm{H}^{-13} \mathrm{C}$ NMR spectra of Lantus ${ }^{\circledR}$ and Basaglar ${ }^{\circledR}$ were used to calculate the chemical shift difference $(\Delta \delta)$. A total of 48 methyl peaks were identified with a signal to noise $(s / n)$ ratio over 10 . The peaks were approximately assigned to amino acid residue types of Ala, Thr, Ile, Leu and Val. Within each amino acid residue type, the peaks were labeled with alphabetic letters. The ${ }^{1} \mathrm{H}$ and ${ }^{13} \mathrm{C}$ chemical shift of each brand were averaged from the spectra of the 5 lots, representing the mean chemical shift of the peak in each brand. Chemical shift difference $(\Delta \delta)$ was the difference between the mean values of Basaglar ${ }^{\circledR}$ and Lantus ${ }^{\circledR}$. 


\subsubsection{Methyl Peak Profile between 2D Spectra}

The peak heights of the 48 identified methyl peaks in $2 \mathrm{D}^{1} \mathrm{H}_{-}{ }^{13} \mathrm{C}$ spectra of Lantus ${ }^{\circledR}$ and Basaglar ${ }^{\circledR}$ were recorded as $I_{x}$ for peak $x$. The relative peak intensity of the peak $x$ (Rel.Int.x) was calculated per Equation (3), where $I_{T h r-d}$ is the peak height of the peak Thr-d, which is the peak with the highest intensity. The mean and standard deviation of Rel.Int.x were calculated from the spectra of 5 different lots within each brand (Table 2). The $p$ value was calculated for each peak $x$ using $t$-test function of two-sample assuming unequal variances in Excel (ver. 16.46). The significant threshold of 0.05 in $p$ value was used to determine the equivalence of relative peak heights. The equation for relative peak intensity is described as follows.

$$
\text { Rel.Int. }=100 \times I_{x} / I_{T h r-d}
$$

\section{Discussion and Conclusions}

\subsection{HOS Inferrred from $1 D$ and $2 D$ Spectra}

In this work, standard NMR experiments using $1 \mathrm{D}^{1} \mathrm{H}, 2 \mathrm{D}{ }^{1} \mathrm{H}-{ }^{13} \mathrm{C}$ HSQC and 2D ${ }^{1} \mathrm{H}_{-}{ }^{15} \mathrm{~N}$ sofast HMQC pulse sequences were performed on formulated protein DPs. The NMR peak patterns from both $1 \mathrm{D}$ and 2D spectra are qualitatively informative for protein HOS properties, providing insight into the oligomerization of liraglutide, the HOS exchange of exenatide and the well folded HOS of calcitonin-salmon, teriparatide, insulin glargine and rituximab. In general, the $1 \mathrm{D}^{1} \mathrm{H}$ NMR experiment provides information on the HOS profile and whether a protein is folded in formulation. Information on more specific HOS variation can be obtained from heteronuclear $2 \mathrm{D}$ spectra. Each $2 \mathrm{D}$ spectrum was sensitive to different aspect of HOS. For example, in the insulin glargine spectra, while the methyl ${ }^{1} \mathrm{H}-{ }^{13} \mathrm{C}$ spectrum showed the sidechains adopting two slowly exchanging conformers, the ${ }^{1} \mathrm{H}_{-}{ }^{15} \mathrm{~N}$ spectrum was more consistent with a single well-folded backbone conformer. The two observations were not necessarily inconsistent with each other, rather, they illustrate the complex nature of protein HOS in the formulation and the atomic level probes used by the different NMR experiments.

\subsection{HOS Similarity Metrics Calculated from $1 D$ and 2D Spectra}

What is different from the pioneering work on demonstrating heteronuclear 2D NMR at protein natural abundance $[41,48,49]$ is that the current study uses NMR on formulated DPs and also includes deriving practically achievable similarity metrics. Earlier work demonstrated the practically achievable Mahalanobis distance $\left(D_{M}\right)$ value of 3.3 based on the PCA of $1 \mathrm{D}^{1} \mathrm{H}$ spectra collected on the marketed insulin reference product and follow-on products [27]. Here, we obtained the $\mathrm{D}_{\mathrm{M}}$ values of 1.95 and 3.15 using PCA and $1 \mathrm{D}^{1} \mathrm{H}$ spectra of rituximab DPs marketed in the US and India, suggesting that a $\mathrm{D}_{\mathrm{M}}$ metrics value of less than 3.3 could be a general acceptance criterion.

While PCA can be conveniently performed on 1D spectra and has been demonstrated on 2D spectra [26,38,50], PCA is challenging to implement for 2D spectra because of the technical complications in binning the 2D spectra and avoiding non-DS peaks at the same time. An alternative method is to focus on the DS peak profile. The normalized distance comparison approach was proposed to compare 2D spectra along the axes of chemical shifts and peak intensity; however, no acceptance criteria were ever proposed [51]. Here the previous chemical shift comparison method [26] was verified using $2 \mathrm{D}^{1} \mathrm{H}_{-}{ }^{13} \mathrm{C}$ spectra collected on insulin glargine DPs and the chemical shift different metrics $(\Delta \delta)$ of $4 \mathrm{ppb}$ for ${ }^{1} \mathrm{H}$ and $15 \mathrm{ppb}$ for ${ }^{13} \mathrm{C}$ were derived. Furthermore, the peak profile method [44] was adopted to compare the relative peak heights between two insulin glargine brands, where $p$ values were derived from $t$-test. In these insulin spectra, $98 \%$ of the methyl cross peaks had equivalent relative peak heights between the two brands. These 2D spectral similarity metrics could be equivalent to the $D_{M}$ value of 1.6 obtained by using $1 \mathrm{D}$ spectra [27]. The methyl peak profile results represent another practically achievable similarity metrics for 2D spectral comparison. 
In summary, the NMR data collected in the current study provided examples of simple experiments and analyses on formulated protein DP and demonstrated practical measurements to assess equivalence of HOS between different DPs. The metrics proposed were validated using marketed similar DPs that were manufactured differently and are proposed as a benchmark to determine the degree of similarity for protein HOS in formulated DPs.

Supplementary Materials: The following are available online. Tables S1-S3 and Matlab code for $\mathrm{D}_{\mathrm{M}}$ calculation.

Author Contributions: Conceptualization, D.A.K. and K.C.; methodology, D.W., D.A.K. and K.C.; validation, D.W. and Y.Z.; investigation, D.W., Y.Z., M.K., S.M.P. and K.C.; writing-original draft preparation, D.W., C.J.S., D.A.K. and K.C.; writing-review and editing, D.W., M.K., S.M.P., C.J.S., D.A.K. and K.C. All authors have read and agreed to the published version of the manuscript.

Funding: This research received no external funding.

Institutional Review Board Statement: Not applicable.

Informed Consent Statement: Not applicable.

Data Availability Statement: The data presented in this study are available in supplementary material.

Acknowledgments: This project was supported, in part, by an appointment (Y.Z. and S.M.P.) to the Research Participation Program at the CDER administered by the Oak Ridge Institute for Science and Education (ORISE) through an interagency agreement between the U.S. Department of Energy and the U.S. FDA.

Conflicts of Interest: The authors declare no conflict of interest.

Disclaimer: This article reflects the views of the author and should not be construed to represent U.S. FDA's views or policies.

Sample Availability: Samples of the compounds are not available from the authors.

\section{References}

1. Zhang, L.; Lionberger, R.A. Generics 2030: Where Are We Heading in 2030 for Generic Drug Science, Research, and Regulation? Clin. Pharmacol. Ther. 2020, 107, 1293-1295. [CrossRef] [PubMed]

2. Christl, L.A.; Woodcock, J.; Kozlowski, S. Biosimilars: The US Regulatory Framework. Annu. Rev. Med. 2017, 68, 243-254. [CrossRef] [PubMed]

3. Fisher, A.C.; Lee, S.L.; Harris, D.P.; Buhse, L.; Kozlowski, S.; Yu, L.; Kopcha, M.; Woodcock, J. Advancing pharmaceutical quality: An overview of science and research in the US FDA's Office of Pharmaceutical Quality. Int. J. Pharm. 2016, 515, 390-402. [CrossRef] [PubMed]

4. Kozlowski, S.; Woodcock, J.; Midthun, K.; Behrman Sherman, R. Developing the Nation's Biosimilars Program. N. Engl. J. Med. 2011, 365, 385-388. [CrossRef] [PubMed]

5. Moussa, E.M.; Panchal, J.P.; Moorthy, B.S.; Blum, J.S.; Joubert, M.K.; Narhi, L.O.; Topp, E.M. Immunogenicity of Therapeutic Protein Aggregates. J. Pharm. Sci. 2016, 105, 417-430. [CrossRef] [PubMed]

6. Gruia, F.; Du, J.; Santacroce, P.V.; Remmele, R.L.; Bee, J.S. Technical Decision Making with Higher Order Structure Data: Impact of a Formulation Change on the Higher Order Structure and Stability of a mAb. J. Pharm. Sci. 2015, 104, 1539-1542. [CrossRef] [PubMed]

7. Aubin, Y.; Hodgson, D.J.; Thach, W.B.; Gingras, G.; Sauvé, S. Monitoring Effects of Excipients, Formulation Parameters and Mutations on the High Order Structure of Filgrastim by NMR. Pharm. Res. 2015, 32, 3365-3375. [CrossRef] [PubMed]

8. Bramham, J.E.; Podmore, A.; Davies, S.A.; Golovanov, A.P. Comprehensive Assessment of Protein and Excipient Stability in Biopharmaceutical Formulations Using 1H NMR Spectroscopy. Acs Pharmacol. Transl. Sci. 2020, 4, $288-295$.

9. Panjwani, N.; Hodgson, D.J.; Sauvé, S.; Aubin, Y. Assessment of the Effects of pH, Formulation and Deformulation on the Conformation of Interferon Alpha-2 by NMR. J. Pharm. Sci. 2010, 99, 3334-3342. [CrossRef]

10. Shah, D.D.; Singh, S.M.; Mallela, K.M.G. Effect of Chemical Oxidation on the Higher Order Structure, Stability, Aggregation, and Biological Function of Interferon Alpha-2a: Role of Local Structural Changes Detected by 2D NMR. Pharm. Res. 2018, 35, 17. [CrossRef]

11. Hodgson, D.J.; Aubin, Y. Assessment of the structure of pegylated-recombinant protein therapeutics by the NMR fingerprint assay. J. Pharm. Biomed. Anal. 2017, 138, 351-356. [CrossRef]

12. Casagrande, F.; Dégardin, K.; Ross, A. Protein NMR of biologicals: Analytical support for development and marketed products. J. Biomol. NMR 2020, 74, 657-671. [CrossRef] 
13. Weiss, W.F.; Gabrielson, J.P.; Al-Azzam, W.; Chen, G.; Davis, D.L.; Das, T.K.; Hayes, D.B.; Houde, D.; Singh, S.K. Technical Decision Making with Higher Order Structure Data: Perspectives on Higher Order Structure Characterization from the Biopharmaceutical Industry. J. Pharm. Sci. 2016, 105, 3465-3470. [CrossRef]

14. Keire, D.A. Analytical Tools for Physicochemical Characterization and Fingerprinting. In Science and Regulations of Naturally Derived Complex Drugs; Sasisekharan, R., Lee, S.L., Rosenberg, A., Walker, L.A., Eds.; Springer International Publishing Ag: Cham, Switzerland, 2019; Volume 32, pp. 91-113.

15. Guerrini, M.; Rudd, T.R.; Yates, E.A. NMR in the Characterization of Complex Mixture Drugs. In Science and Regulations of Naturally Derived Complex Drugs; Sasisekharan, R., Lee, S.L., Rosenberg, A., Walker, L.A., Eds.; Springer International Publishing Ag: Cham, Switzerland, 2019; Volume 32, pp. 115-137.

16. Amezcua, C.A.; Szabo, C.M. Assessment of Higher Order Structure Comparability in Therapeutic Proteins Using Nuclear Magnetic Resonance Spectroscopy. J. Pharm. Sci. 2013, 102, 1724-1733. [CrossRef]

17. Arbogast, L.W.; Brinson, R.G.; Formolo, T.; Hoopes, J.T.; Marino, J.P. 2D 1HN, 15N Correlated NMR Methods at Natural Abundance for Obtaining Structural Maps and Statistical Comparability of Monoclonal Antibodies. Pharm. Res. 2016, 33, 462-475. [CrossRef]

18. Arbogast, L.W.; Brinson, R.G.; Marino, J.P. Mapping Monoclonal Antibody Structure by 2D 13C NMR at Natural Abundance. Anal. Chem. 2015, 87, 3556-3561. [CrossRef]

19. Kiss, R.; Fizil, Á.; Szántay, C. What NMR can do in the biopharmaceutical industry. J. Pharm. Biomed. Anal. 2018, 147, 367-377. [CrossRef]

20. Chen, K.; Long, D.S.; Lute, S.C.; Levy, M.J.; Brorson, K.A.; Keire, D.A. Simple NMR methods for evaluating higher order structures of monoclonal antibody therapeutics with quinary structure. J. Pharm. Biomed. Anal. 2016, 128, 398-407. [CrossRef]

21. Hodgson, D.J.; Ghasriani, H.; Aubin, Y. Assessment of the higher order structure of Humira ${ }^{\circledR}, \operatorname{Remicade}^{\circledR}$, Avastin $^{\circledR}, \operatorname{Rituxan}^{\circledR}$, Herceptin $^{\circledR}$, and Enbrel ${ }^{\circledR}$ by 2D-NMR fingerprinting. J. Pharm. Biomed. Anal. 2019, 163, 144-152. [CrossRef]

22. Japelj, B.; Ilc, G.; Marušič, J.; Senčar, J.; Kuzman, D.; Plavec, J. Biosimilar structural comparability assessment by NMR: From small proteins to monoclonal antibodies. Sci. Rep. 2016, 6, 32201. [CrossRef]

23. Elliott, K.W.; Ghasriani, H.; Wikström, M.; Giddens, J.P.; Aubin, Y.; Delaglio, F.; Marino, J.P.; Arbogast, L.W. Comparative Analysis of One-Dimensional Protein Fingerprint by Line Shape Enhancement and Two-Dimensional 1H,13C Methyl NMR Methods for Characterization of the Higher Order Structure of IgG1 Monoclonal Antibodies. Anal. Chem. 2020, 92, 6366-6373. [CrossRef] [PubMed]

24. Franks, J.; Glushka, J.N.; Jones, M.T.; Live, D.H.; Zou, Q.; Prestegard, J.H. Spin Diffusion Editing for Structural Fingerprints of Therapeutic Antibodies. Anal. Chem. 2016, 88, 1320-1327. [CrossRef] [PubMed]

25. Poppe, L.; Jordan, J.B.; Lawson, K.; Jerums, M.; Apostol, I.; Schnier, P.D. Profiling Formulated Monoclonal Antibodies by 1H NMR Spectroscopy. Anal. Chem. 2013, 85, 9623-9629. [CrossRef] [PubMed]

26. Ghasriani, H.; Hodgson, D.J.; Brinson, R.G.; McEwen, I.; Buhse, L.F.; Kozlowski, S.; Marino, J.P.; Aubin, Y.; Keire, D.A. Precision and robustness of 2D-NMR for structure assessment of filgrastim biosimilars. Nat. Biotechnol. 2016, 34, 139. [CrossRef]

27. Wang, D.; Park, J.; Patil, S.M.; Smith, C.J.; Leazer, J.L., Jr.; Keire, D.A.; Chen, K. An NMR-Based Similarity Metric for Higher Order Structure Quality Assessment Among, U.S. Marketed Insulin Therapeutics. J. Pharm. Sci. 2020, 109, 1519-1528. [CrossRef]

28. Ionova, Y.; Wilson, L. Biologic excipients: Importance of clinical awareness of inactive ingredients. PLoS ONE 2020, 15, e0235076. [CrossRef]

29. Wishart, D.S.; Knox, C.; Guo, A.C.; Eisner, R.; Young, N.; Gautam, B.; Hau, D.D.; Psychogios, N.; Dong, E.; Bouatra, S.; et al. HMDB: A knowledgebase for the human metabolome. Nucleic Acids Res. 2009, 37, 603-610. [CrossRef]

30. Ulrich, E.L.; Akutsu, H.; Doreleijers, J.F.; Harano, Y.; Ioannidis, Y.E.; Lin, J.; Livny, M.; Mading, S.; Maziuk, D.; Miller, Z.; et al. BioMagResBank. Nucleic Acids Res. 2008, 36, 402-408. [CrossRef]

31. Patil, S.M.; Li, V.; Peng, J.; Kozak, D.; Xu, J.; Cai, B.; Keire, D.A.; Chen, K. A Simple and Noninvasive DOSY NMR Method for Droplet Size Measurement of Intact Oil-In-Water Emulsion Drug Products. J. Pharm. Sci. 2019, 108, 815-820. [CrossRef]

32. Wang, W.; Ignatius, A.A.; Thakkar, S.V. Impact of Residual Impurities and Contaminants on Protein Stability. J. Pharm. Sci. 2014, 103, 1315-1330. [CrossRef]

33. Gottlieb, H.E.; Kotlyar, V.; Nudelman, A. NMR Chemical Shifts of Common Laboratory Solvents as Trace Impurities. J. Org. Chem. 1997, 62, 7512-7515. [CrossRef]

34. Malmstrøm, J. Quantification of Silicone Oil and Its Degradation Products in Aqueous Pharmaceutical Formulations by 1H-NMR Spectroscopy. J. Pharm. Sci. 2019, 108, 1512-1520. [CrossRef]

35. Suh, M.S.; Patil, S.M.; Kozak, D.; Pang, E.; Choi, S.; Jiang, X.; Rodriguez, J.D.; Keire, D.A.; Chen, K. An NMR Protocol for In Vitro Paclitaxel Release from an Albumin-Bound Nanoparticle Formulation. AAPS Pharmscitech 2020, 21, 136. [CrossRef]

36. Skidmore, K.; Hewitt, D.; Kao, Y.-H. Quantitation and characterization of process impurities and extractables in protein-containing solutions using proton NMR as a general tool. Biotechnol. Prog. 2012, 28, 1526-1533. [CrossRef]

37. Palmer, A.G.; Kroenke, C.D.; Patrick Loria, J. Nuclear Magnetic Resonance Methods for Quantifying Microsecond-to-Millisecond Motions in Biological Macromolecules. In Methods in Enzymology; James, T.L., Dötsch, V., Schmitz, U., Eds.; Academic Press: Cambridge, MA, USA, 2001; Volume 339, pp. 204-238.

38. Chen, K.; Park, J.; Li, F.; Patil, S.M.; Keire, D.A. Chemometric Methods to Quantify 1D and 2D NMR Spectral Differences among Similar Protein Therapeutics. AAPS Pharmscitech 2018, 19, 1011-1019. [CrossRef] 
39. Chang, X.; Jørgensen, A.M.M.; Bardrum, P.; Led, J.J. Solution Structures of the R6 Human Insulin Hexamer. Biochemistry 1997, 36, 9409-9422. [CrossRef]

40. Quinternet, M.; Starck, J.P.; Delsuc, M.A.; Kieffer, B. Heteronuclear NMR provides an accurate assessment of therapeutic insulin's quality. J. Pharm. Biomed. Anal. 2013, 78, 252-254. [CrossRef]

41. Brinson, R.G.; Marino, J.P.; Delaglio, F.; Arbogast, L.W.; Evans, R.M.; Kearsley, A.; Gingras, G.; Ghasriani, H.; Aubin, Y.; Pierens, G.K.; et al. Enabling adoption of 2D-NMR for the higher order structure assessment of monoclonal antibody therapeutics. $m A b s$ 2019, 11, 94-105. [CrossRef]

42. Nishizaki, Y.; Lankin, D.C.; Chen, S.-N.; Pauli, G.F. Accurate and Precise External Calibration Enhances the Versatility of Quantitative NMR (qNMR). Anal. Chem. 2021, 93, 2733-2741. [CrossRef]

43. Schanda, P.; Brutscher, B. Very Fast Two-Dimensional NMR Spectroscopy for Real-Time Investigation of Dynamic Events in Proteins on the Time Scale of Seconds. J. Am. Chem. Soc. 2005, 127, 8014-8015. [CrossRef]

44. Zhuo, Y.; Keire, D.A.; Chen, K. Minor N-Glycan Mapping of Monoclonal Antibody Therapeutics Using Middle-Down NMR Spectroscopy. Mol. Pharm. 2021, 18, 441-450. [CrossRef] [PubMed]

45. Delaglio, F.; Grzesiek, S.; Vuister, G.W.; Zhu, G.; Pfeifer, J.; Bax, A. Nmrpipe-a Multidimensional Spectral Processing System Based on Unix Pipes. J. Biomol. NMR 1995, 6, 277-293. [CrossRef] [PubMed]

46. Wishart, D.S.; Bigam, C.G.; Yao, J.; Abildgaard, F.; Dyson, H.J.; Oldfield, E.; Markley, J.L.; Sykes, B.D. 1H, 13C and 15N chemical shift referencing in biomolecular NMR. J. Biomol. NMR 1995, 6, 135-140. [CrossRef] [PubMed]

47. Brereton, R.G. The Mahalanobis distance and its relationship to principal component scores. J. Chemom. 2015, $29,143-145$. [CrossRef]

48. Aubin, Y.; Gingras, G.; Sauvé, S. Assessment of the Three-Dimensional Structure of Recombinant Protein Therapeutics by NMR Fingerprinting: Demonstration on Recombinant Human Granulocyte Macrophage-Colony Stimulation Factor. Anal. Chem. 2008, 80, 2623-2627. [CrossRef]

49. Chen, K.; Freedberg, D.I.; Keire, D.A. NMR profiling of biomolecules at natural abundance using $2 \mathrm{D} 1 \mathrm{H}-15 \mathrm{~N}$ and $1 \mathrm{H}-13 \mathrm{C}$ multiplicity-separated (MS) HSQC spectra. J. Magn. Reson. 2015, 251, 65-70. [CrossRef]

50. Arbogast, L.W.; Delaglio, F.; Schiel, J.E.; Marino, J.P. Multivariate Analysis of Two-Dimensional 1H, 13C Methyl NMR Spectra of Monoclonal Antibody Therapeutics To Facilitate Assessment of Higher Order Structure. Anal. Chem. 2017, 89, 11839-11845. [CrossRef]

51. Haxholm, G.W.; Petersen, B.O.; Malmstrøm, J. Higher-Order Structure Characterization of Pharmaceutical Proteins by 2D Nuclear Magnetic Resonance Methyl Fingerprinting. J. Pharm. Sci. 2019, 108, 3029-3035. [CrossRef] 